\title{
MORPHOLOGICAL AND PETROGRAPHIC ANALYSIS OF NEWLY IDENTIFIED STROMATOLITIC OCCURRENCES IN THE LAGOA DO JACARÉ FORMATION, BAMBUÍ GROUP, STATE OF MINAS GERAIS, BRAZIL
}

\author{
DANIEL MARTINS DOS SANTOS \\ Programa de Pós-Graduação em Geologia, Universidade de Brasília, Campus Universitário Darcy Ribeiro, 70910-900, \\ Brasília, DF, Brazil. danielmartinsuk@gmail.com
}

EVELYN A. M. SANCHEZ

Universidade Federal dos Vales do Jequitinhonha e Mucuri, Campus JK, Rodovia MGT 367, Km 583, $\mathrm{n}^{\circ} 5000$ Alto da Jacuba, 39100-000, Diamantina, MG, Brazil.evelyn.sanchez@ict.ufvjm.edu.br

RODRIGO MILONI SANTUCCI

Universidade de Brasília, Campus Planaltina, Área Universitária n¹, Vila Nossa Senhora de Fátima, 73345-010, Planaltina, DF, Brazil.rodrigoms@unb.br

\begin{abstract}
Here we catalog, for the first time, the known stromatolite-containing localities and morphologies found in outcrops previously attributed, by past mapping efforts, to the Lagoa do Jacaré Formation, Bambuí Group. Unlike the Sete Lagoas Formation, which has already provided several crucial samples containing a substantial variety of microbialitic forms and microfossils, the fossiliferous potential of the Lagoa do Jacaré Formation has not been properly assessed. Surprisingly, a relatively diverse variety of forms was found, including domal, various columnar, laminites and columnar-layered stromatolites. Morphological and petrographical descriptions were made and six microfabrics were unveiled, shedding light into the environmental conditions likely to have been involved in their formation.
\end{abstract}

Keywords: stromatolites, Lagoa do Jacaré Formation, Bambuí Group.

RESUMO - Apresentamos aqui, descrições morfológicas e petrográficas de novas ocorrências de estromatólitos de diferentes morfologias, incluindo formas colunares, dômicas e estratiformes, atribuídas a Formação Lagoa do Jacaré, Grupo Bambuí, nas regiões norte e sul do Estado de Minas Gerais. O presente trabalho contribui com o entendimento do registro fóssil da Formação Lagoa do Jacaré, que ainda permanece inexplorado em comparação com outros ciclos carbonáticos do Grupo Bambuí, como a Formação Sete lagoas. Os dados texturais e morfológicos foram utilizados para discutir possíveis paleoambientes e regimes de deposição.

Palavras-chave: estromatólitos, Formação Lagoa do Jacaré, Grupo Bambuí.

\section{INTRODUCTION}

The Bambuí Group corresponds to a siliciclastic and carbonate succession, deposited over three transgressiveregressive megacycles, in a basin that developed as a response to the Brasiliano orogenic cycle and the rise of the Brasília Fold Belt (Martins-Neto, 2007; Sial et al., 2009; Pimentel et al., 2011; Uhlein et al., 2017). The group covers vast areas of the São Francisco Craton and the Brasília Fold Belt, being present in over five Brazilian states, including Minas Gerais, Bahia, Goiás, Tocantins, and the Federal District territory (Dardenne, 2000).

The current stratigraphic division of the Bambuí Group only emerged in the second half of the last century, with the mapping and stratigraphic work conducted by Costa
\& Branco (1961), later expanded by Dardenne (1978a,b, 1979, 2000). They identified and defined five geological formations and their respective stratigraphic sequence, laying the foundations of the modern nomenclature of the succession. These consist of, from the bottom to the top, the dolomites and stromatolitic limestones of the Sete Lagoas Formation; the shales, siltstones and marls of the Serra de Santa Helena Formation; the calcarenites, oolitic and oncolitic limestones of the Lagoa do Jacaré Formation; the shales and siltstones of the Serra da Saudade Formation; and the arkoses, sandstones, and conglomerates characteristic of the Três Marias Formation. Recently, new formations were added to Bambuí Group in its occurrence at the State of Minas Gerais, such as the Gorutuba Formation, exemplified by the work of Kuchenbecker et al. (2016). 
Depositional age. The depositional ages obtained for the Bambuí Group varied greatly since the 1920's, and continued to do so in the past decade of published research. Early workers such as Derby (1880) and Maury (1929) recognized putative tabulate corals in the limestones of the region of Bom Jesus da Lapa, in the State of Bahia, which were used to estimate a Silurian age for the succession. That notion changed in the 1970's, after a series of papers published by Marchese (1974), who analyzed the morphology and the biostratigraphic distribution of microbialitic occurrences in the Sete Lagoas Formation and proposed a Precambrian age for the Bambuí Group, which remained popular in the literature until recently. Babinski et al. (2007) dated the post-glacial cap carbonate sequence of the Sete Lagoas Formation at Inhaúma, State of Minas Gerais, using Pb-Pb isochron dating methods, and obtained a maximum age of $740 \pm 22 \mathrm{Ma}$. This enabled the authors to suggest a possible correlation between the Sete Lagoas Formation and the post-glacial record of the Sturtian Glaciation, in middle to late Cryogenian.

Rodrigues (2008), utilizing detrital zircons from the upper portion of the Sete Lagoas Formation, estimated a maximum age limit of $610 \mathrm{Ma}$, while a similar work done by Pimentel et al. (2011) resulted in an age of $620 \mathrm{Ma}$. Unpublished work presented at conferences showed a significant population of detrital zircon crystals with maximum ages of $540 \mathrm{Ma}$ (Pimentel, 2012; Paula-Santos et al., 2012).

A newly obtained maximum depositional age for the upper part of the Sete Lagoas Formation of 557 Ma was also recognized, strongly suggesting that sedimentation of most of the sequence started in the late Ediacaran, and that its basal cap carbonate sequence could not be correlated with neither the Sturtian nor the Marinoan glaciations of the Cryogenian-Ediacaran periods (Paula-Santos et al., 2015). This upper age constraint echoes the suggestion by Kuchenbecker (2014) that glacial deposits underlying the Bambuí Group could be correlated with younger equivalent events in the Nama Basin, with estimated ages between 548-542 Ma.

A possible correlation with the Gaskiers Glaciation remains to be investigated, though there are possible coeval deposits reported in the Ediacaran of the Paraguay Belt (Alvarenga et al., 2007). New evidence coming from a different and independent front, seems to strongly corroborate a late Ediacaran age for the deposition of the upper portion of the Sete Lagoas Formation, such as the discovery of reworked fragments of body fossils of the mineralized metazoans Cloudina sp. and Corumbella werneri Hahn et al., 1982 by Warren et al. (2014). Cloudina possesses a global distribution and a biozone with an estimated range between 550-543 Ma (Grotzinger et al., 2000).

The most parsimonious age interpretation for the Bambuí Group today, given the most recent evidence cited above, is that its most basal unit, the Sete Lagoas Formation, was deposited entirely in the Ediacaran Period, with the upper portion likely being deposited in the very latest Ediacaran, close to the Proterozoic-Phanerozoic boundary. The remaining units, the Serra de Santa Helena, Lagoa do Jacaré, Serra da Saudade and Três Marias formations could possibly have been deposited in the early to middle Cambrian (PaulaSantos et al., 2018).

The Lagoa do Jacaré Formation. The sedimentology of the Lagoa do Jacaré Formation has been long recognized as being constituted of dark, often fetid limestones, but also of oncolitic and oolitic calcarenites and calcirudites (Dardenne, 1978a,b). This definition, as well as the stratigraphy of the formation, is being expanded in recent years mostly due to work being conducted at the local level by authors such as Iglesias \& Uhlein (2009), who proposed a stratigraphic model for the Bambuí Group in the northern portion of the basin, in the São Francisco valley, a region which encompasses two important outcrops analyzed in this study.

There, the Lagoa do Jacaré Formation could be subdivided into three distinct lithofacies, the basalmost consisting of calcarenites and calcisiltones with common intraclastic breccias and chert nodules, followed upwards by impure limestones and culminating in the uppermost horizon composed of siltstones and calcisiltstones (marls). The southern regions have also received similar attention, and calcarenitic and calcisiltitic lithofacies with oolitic to pisolitic and rarer intraclastic instances were described (Kuchenbecker \& Pedrosa-Soares, 2013).

The interpretations regarding the inferred depositional environments for the Lagoa do Jacaré tend to converge into a shallow, proximal carbonate platform where sedimentation would be influenced by wave motion and tidal cycles, with occasional subaerial exposure and disturbance by stormlike events.

Reported fossil sites within the Lagoa do Jacaré Formation consist exclusively of locally found stromatolitic sites (Ribeiro et al., 2008; Iglesias \& Uhlein, 2009; Costa, 2011; Cunha, 2012; Fragoso et al., 2013; Kuchenbecker \& Pedrosa-Soares, 2013; Sanchez, 2014). In relation to the stratigraphic placement of these reported stromatolitic occurrences, the northern ones could be roughly established to occur in the lowermost lithofacies as defined by Iglesias \& Uhlein (2009). This stands in contrast with the southern reported occurrences which were not presented with accompanying indicators of their stratigraphic positioning within the formation itself.

Despite having been reported before, none of these new occurrences have been thoroughly described and studied. Our goal consisted of revising the literature in search of past reports of stromatolite-bearing outcrops belonging to the Lagoa do Jacaré Formation as well as conducting follow up field excursions to confirm and describe new sites.

Here we report abundant new occurrences of morphologically diverse stromatolites in sites located in the northern and southern portions of the State of Minas Gerais, selected from previous works, which identified outcrops belonging to the Lagoa do Jacaré Formation (Ribeiro et al., 2008; Iglesias \& Uhlein, 2009; Costa 2011; Cunha, 2012; Fragoso et al., 2013; Kuchenbecker \& Pedrosa-Soares, 2013; Sanchez, 2014). 
This is the first complete and detailed analysis, including both macroscopic and petrographic descriptions, to specifically deal with Lagoa do Jacaré Formation stromatolitic occurrences. The presence of microbialitic forms in the limestones of the Lagoa do Jacaré Formation brings to light the need for revision of its sedimentological and faciological definitions, which currently do not include such information. Additionally, the data presented in the following sections alters our current understanding of the paleobiota present in the Bambuí Group during the Lagoa do Jacaré deposition interval, increasing its known diversity.

\section{MATERIAL AND METHODS}

Two field campaigns were conducted and fossiliferous sites were found near the cities of Luz, Bom Despacho, Jaíba and São João da Ponte in the State of Minas Gerais (Figure 1; Table 1).The descriptions herein presented follow the parameters established by Logan et al. (1964) in his pioneering work with modern columnar stromatolites in Shark Bay, Australia. We start by providing a detailed macroscopic and morphological description, followed by similar pursuits in the mesoscopic and microscopic levels, with the assistance of thin section analysis. Slabs were produced by cutting through samples to study their morphology and synoptic profile, like what has been described in Preiss (1976).

Descriptions at the macro- and mesoscopic levels were informed by the guiding work of Fairchild \& Sanchez (2015), while petrographic analyses followed the nomenclature established by the work of Riding $(1977,1991,2008)$, and the descriptions of the microbialites found at Sete Lagoas Formation outcrops by Sanchez (2014). Thin sections were observed and analyzed using an Olympus BX 41 polarizedlight microscope, and photomicrographs were obtained utilizing Axio Scope.A1 Polarized Light Microscope and the camera AxioCam Icc 1, both from ZEISS ${ }^{\circledR}$.
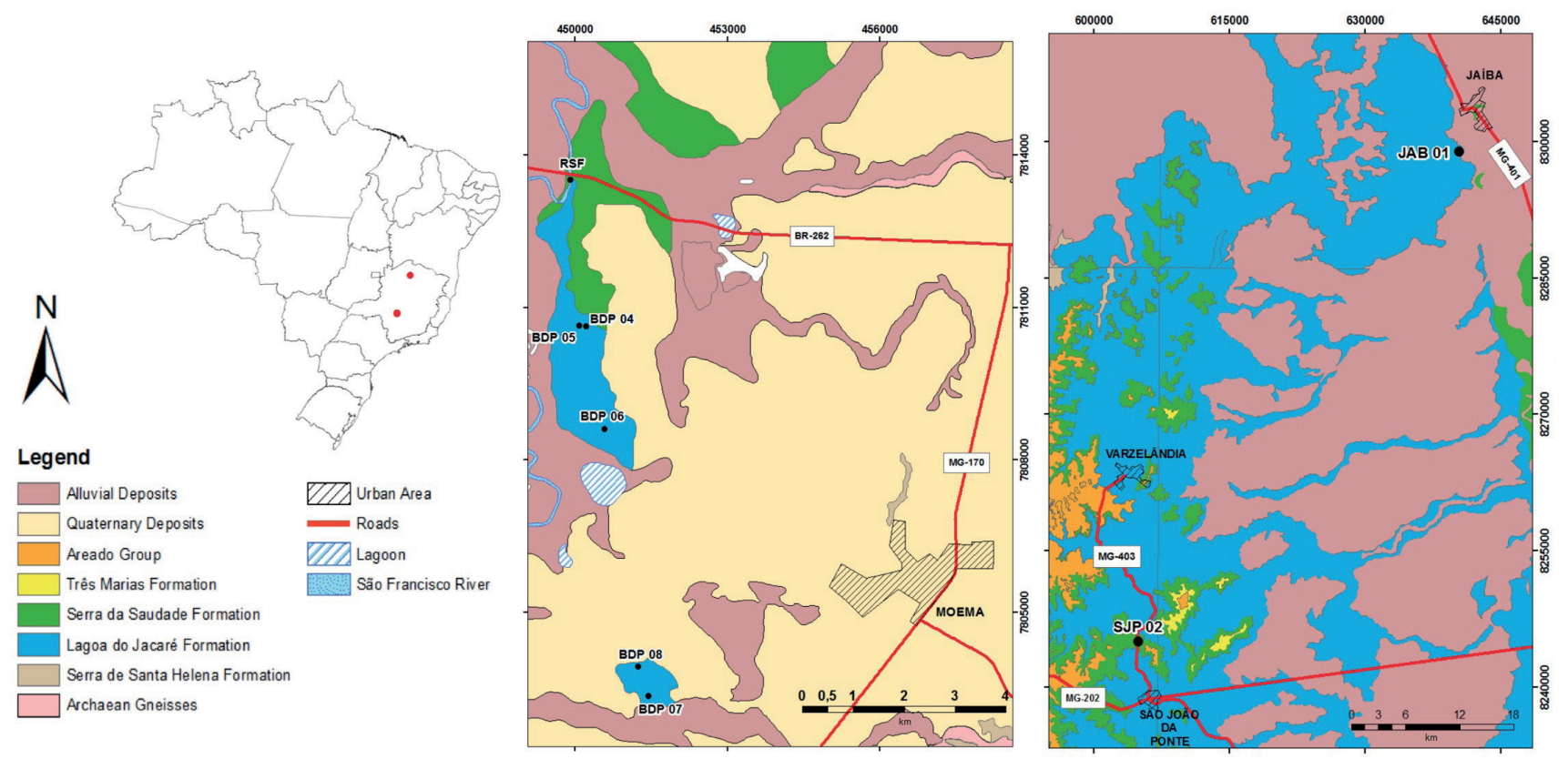

Figure 1. Geographical locations of the fossiliferous sites (red dots) within the State of Minas Gerais, Brazil, followed by two local geological maps showing the lithological context of both the southern localities (on the left) and the northern localities (on the right). Specific coordinates shown in UTM are listed in Table 1.

Table 1. Publications with verified occurrence of stromatolitic outcrops are listed below, alongside their locality, specific coordinates and initials used.

\begin{tabular}{ccc}
\hline Locality & Coordinates (UTM) & Publication \\
\hline São João da Ponte, MG & 0604887 E/8244951N (SJP-2) & Iglesias \& Uhlein (2009) \\
& 450234 E/7810630 N (BDP-4) & Ribeiro et al. (2008) \\
Bom Despacho, MG & 450099 E/7810647 N (BDP-5) & Costa (2011) \\
& 450099 E/7810647 N (BDP-6) & Kuchenbecker \& Pedrosa-Soares (2013) \\
\hline
\end{tabular}




\section{RESULTS}

Morphological description. Of all the Lagoa do Jacaré Formation outcrops reported in the literature to possess stromatolite-bearing limestone outcrops, only four could be confirmed by our field excursions (Table 1): in the extreme north of the State of Minas Gerais, close to the border with the State of Bahia, near the municipalities of Jaíba (samples labelled JAB) and São João da Ponte (samples labelled SJP), and in the southern region of the state, between the cities of Luz (Rio São Francisco outcrop, samples also labelled RSF) and Bom Despacho (samples labelled BDP).

The Rio São Francisco outcrop (RSF) is found at the margins of the São Francisco River, directly below a bridge, accessible by car, between the Luz and Moema municipalities and may be described as a roughly 4-meter-thick carbonate succession characterized by two microbialitic horizons, separated by strata of calcarenites and calcirudites (Figure 2A). The coarse-grained carbonate sediments seem to have an erosional contact with the basal stromatolitic-bearing strata. The lower portion of the outcrop is defined by extensive biostromes comprised of closely packed, continuous, decimetric, uniform, cylindrical columns (height>width) with well-defined margins and multiple growth vectors (Figures 2B-C). These rarely develop branches and are characterized by a lack of intercolumnar material between structures. At plan view columns form circular to irregular morphologies which often develop intergrowth.

The stromatolites found in the upper portion of the RSF outcrop differ substantially from the ones found at lower horizons. They are dominated by individual columns with widths that increase vertically and divergent branching patterns $\left(20^{\circ}-45^{\circ}\right)$ with branches also possessing columnar forms (Figures 2D-E). Intercolumnar material occur in the form of oolitic, oncolitic and intraclastic grainstones, which commonly interfered with microbial growth. Lamina shape of both morphologies is generally symmetric, slightly to moderately convex with one degree of curvature. Vertical inheritance is moderate to good, and margins are smooth. Laminations at the apical portions of columns were observed to develop parabolic or coniform morphologies (Figure 2C).

A relatively diverse assemblage of stromatolitic forms was found at the localities near the city of Bom Despacho, first reported by Ribeiro et al. (2008). The region yielded densely-packed columnar stromatolites at sites BDP-4, BDP-7, and BDP-8, which are here described as possessing vertical and sinuous growth vectors, with little to no space between columns (directly adjacent to each other) and bridges connecting the structures (Figures 3A-C). Columnar stromatolites with rapid vertical change in width were also observed to have locally been formed (Figure 3D). Both symmetrical and asymmetrical lamina shapes occur, and are commonly moderately to strongly convex, with moderate vertical inheritance. Circular and irregular morphologies were observed at plan view.

At the sites labelled BDP-5 and BDP-6, stromatolites occurred as part of locally-developing karst systems, exposing multiple-meter-high carbonate walls, which allowed the observation of vertical variation between forms (Figure 4A). The stromatolites here were found to be moderately preserved, their margins and laminations, though altered by dissolution surfaces, are still distinguishable. These occur as tabular stromatolitic bodies (biostromes) that extend laterally in an intertwined sequence of strata dominated by the development of columnar-layered stromatolites and strata comprised of lowsynoptic relief forms such as laminites. Microbialitic laminites occur as flat, wavy layers of coarse-grained carbonate deposits whereas columnar-layered forms present themselves in cross section as columns with vertical growth vectors, turbinate accretion patterns, as well as beta- and alpha-type branching patterns (Figures 4B-C). Branches are also columnar in shape and form bridges. These columnar forms tend to coalesce upwards into low-synoptic relief stratiform morphologies, forming a dynamic system (Figure 4C). Lamina shape varies between horizontal to slightly and moderately convex with one order of curvature. Morphologies at plan view could not be determined due to a lack of proper exposures.

At the São João da Ponte region, it was possible to confirm to presence of columnar stromatolite morphologies, as first indicated by Iglesias \& Uhlein (2009), as well a large domal stromatolite form. These stromatolites were observed alongside a decametric, road cut-type outcrop, which is easily accessible by car. Bioherms were commonly associated with intraclastic calcirudites. The columnar stromatolites occurred as isolated fragmented bioherm blocks alongside the road cut presenting poor to moderate preservation (Figure 5A). Columns are closely arranged, decimetric, cylindrical, and uniform in shape with sinuous growth vectors. Branching is common and follow parallel trends, where branches diverge less than $20^{\circ}$ from each other, representing alpha and beta-type patterns, with no or some increase in column width before the branching takes place, respectively (Figures 5A-B). Branches are also cylindrical, in a digitate mode. Basal portions were found to have developed bridges between columns. The laminations may overlap, being mostly asymmetric, moderately to steeply convex (coniform at the axial zone) with one order of curvature and moderate vertical inheritance.

The latter domal stromatolite may be characterized as a meter-long isolated domal morphotype with good preservation. Basal laminae are rhombic-shaped, overlap each other forming a partial wall and vertically transition to symmetrical and moderately convex laminations with two orders of laminar curvature (convex or curved laminations which themselves are crenulated). A light-dark alternation pattern is clearly visible (Figures 5D-C). Vertical inheritance is good.

The last locations visited, which resulted in a confirmation of fossiliferous sites, were the ones reported by Costa (2011) near the city of Jaíba. There, dome-shaped stromatolitic bioherms (Figure 6A) were found in lateral contact with vast deposits of intraclastic calcirudites. Advanced stages of weathering took place and stromatolitic columns are poorly to moderately preserved, with laminations often erased or only faintly visible. Columns are tuberous with sinuous growth vectors, forming bumps that penetrate the adjacent 


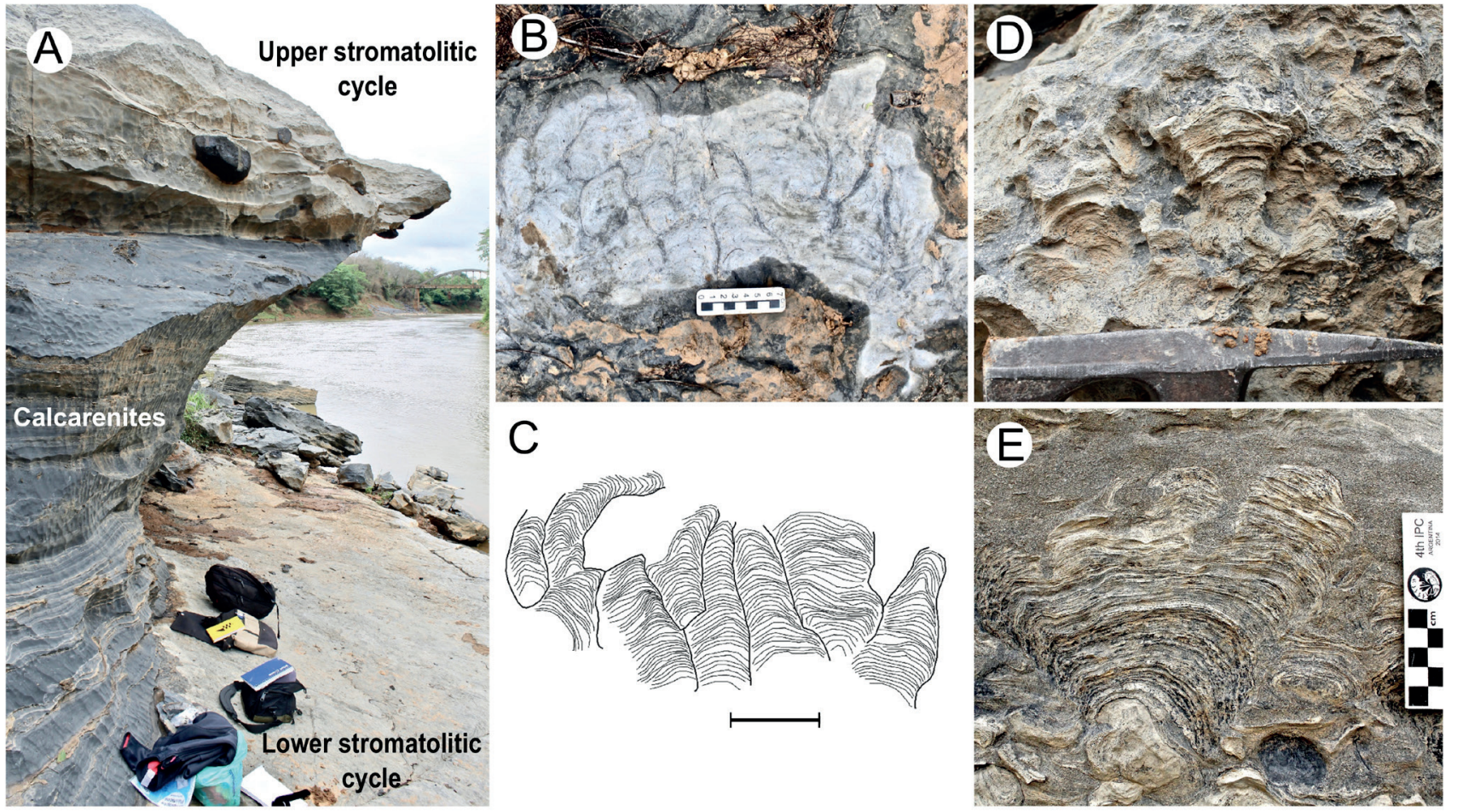

Figure 2. A, overview of the RSF outcrop showing the basal stromatolitic cycle followed by deposition of thick grainstone strata, which in turn is overlain by the return of microbial deposits. B-C, longitudinal view of the densely packed columnar stromatolites found at the lower cycle and schematic drawing highlighting laminae shape and column morphology. D-E, typical stromatolitic columns with turbinate growth observed at the upper most stromatolitic cycle. Note the intense deposition of coarse-grained sediments, (geological hammer is approximately $28 \mathrm{~cm}$ in length). Scale bar in $\mathrm{C}=7 \mathrm{~cm}$.

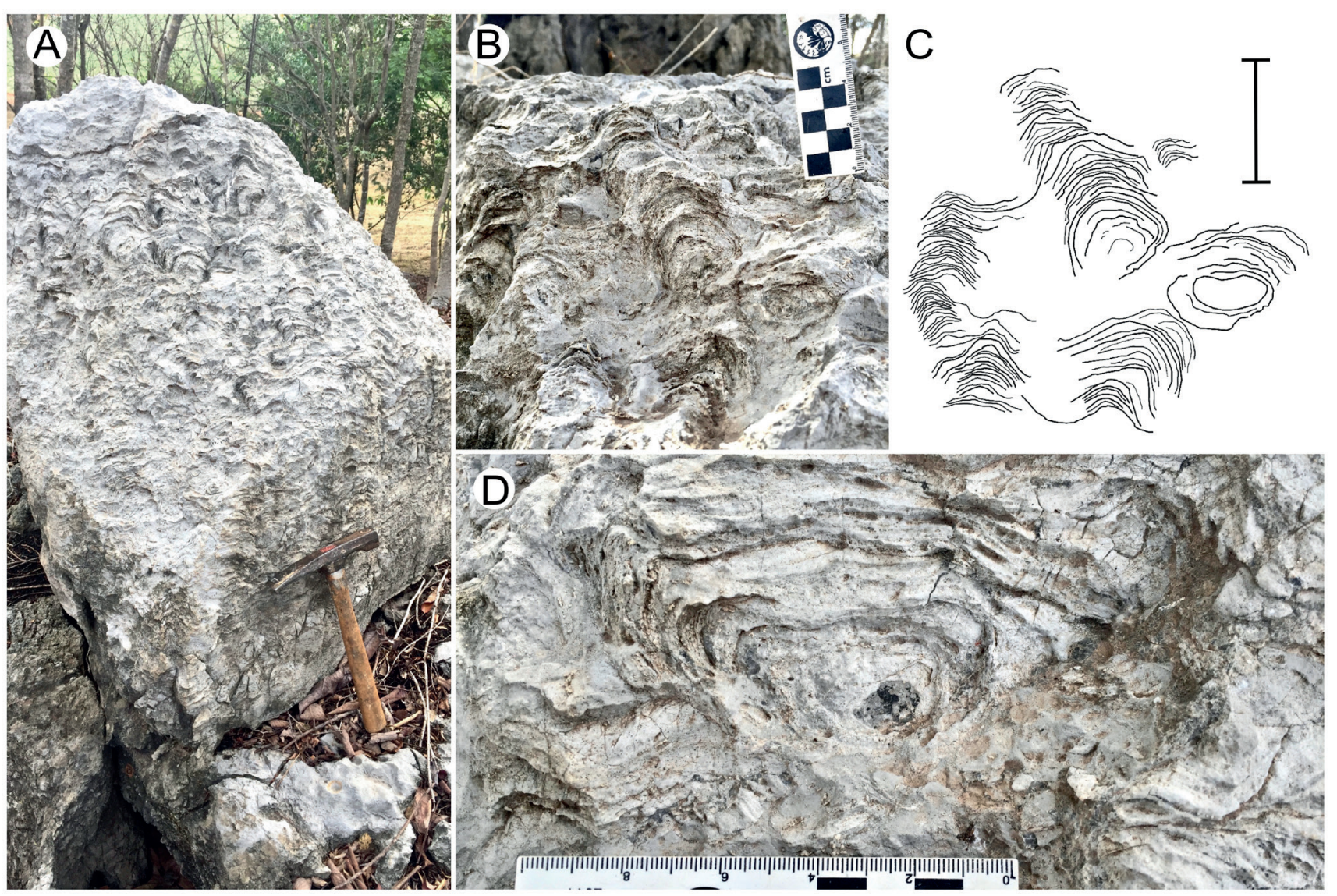

Figure 3. A, field photograph showing common bioherm morphology found in the sites reported by Ribeiro et al. (2008) and the columnar stromatolites of which they are formed (geological hammer is approximately $28 \mathrm{~cm}$ in length). B-C, columnar stromatolites with little to no space between structures and locally developed bridges. Note the sinuous aspects of their growth vectors. $\mathbf{D}$, example of columnar stromatolite with turbinate growth pattern. $\mathrm{Scale}$ bar: $\mathrm{C}=5 \mathrm{~cm}$. 
intercolumnar sediment (Figure 6B). Column diameter is larger than the space between the structures, which is filled with marl sediments. Branches are rare but when present they are slightly divergent and columnar (Figure 6B). Turbinate growth patterns also occur locally. Equidimensional, elliptical and elongated forms are found when these stromatolites are seen in plan view (Figure 6C). Laminae are uneven and often discontinuous, possessing low synoptic relief, with only a few tenths of a centimeter measured for a single lamination. They are also slightly to moderately convex, generally developing a wavy pattern with two orders of curvature. Vertical inheritance is low to moderate.

Microfabrics. Petrographical analysis of selected thin sections revealed an assemble of commonly-occurring stromatolitic microfabrics along with some localized portions characterized by the development of rarer filamentous-like and shrub-like microfabrics (Table 2). The most common microtextures observed were: (i) dense micrite microfabrics (Figure 7A), defined here as homogeneous, generally aphanitic, laterally continuous masses of dark micrite rich in organic matter; (ii) fenestral clotted microfabrics (Figures 7B-C), observed to be formed by aggregates or clumps of dark micrite, usually tens to hundreds of microns across, defining irregular pores or fenestrae; (iii) peloidal microfabrics (Figure 7D) characterized by collections of sub-rounded to rounded, transported peloids of varying sizes, with well-defined margins embedded within a carbonate mud (micrite) matrix or cement; (iv) homogeneous microsparitic microfabrics, occurring as laterally continuous masses of clear, often subhedral to euhedral siltsized calcite crystals; (v) Sparry calcite microfabric (Figure 7E), which presents itself as large, subhedral to euhedral equigranularcrystals of calcite in granular texture.

The columnar stromatolites found at the RSF outcrop, both on the lower and upper portions, were essentially comprised of sub-millimetric to millimetric organic laminae formed by dense micrite and fenestral clotted microfabrics,
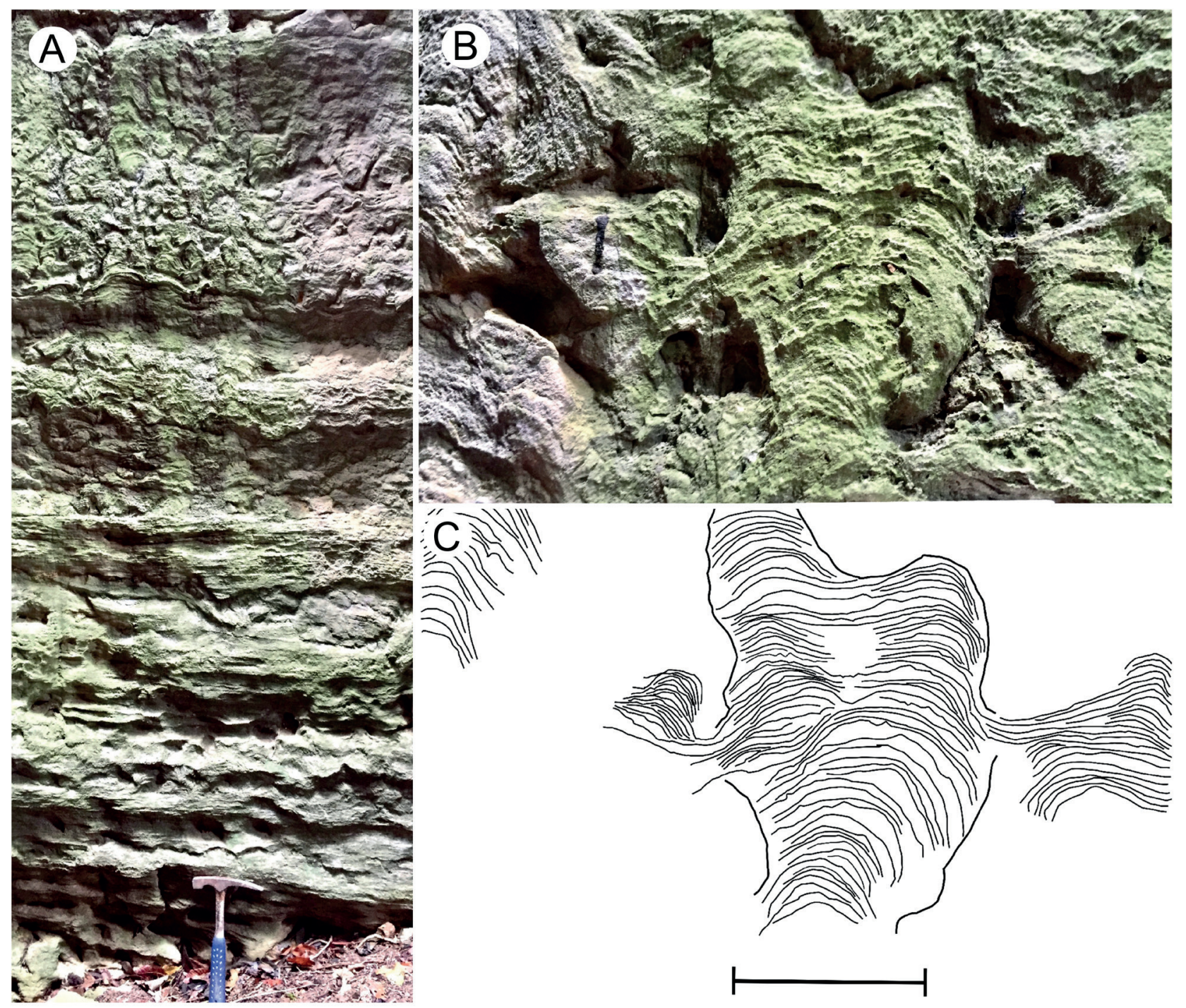

Figure 4. A, a roughly 2-meter-tall carbonate outcrop composed of alternating strata with different stromatolitic morphologies (geological hammer is approximately $28 \mathrm{~cm}$ in length). At the very base of the succession there is a predominance of laminites or low synoptic relief stromatolites, which vertically give space to columnar-layered forms. B-C, close-up view of a single columnar-layered form and its respective digital drawing. Structure starts as a single column with turbinate growth, transitioning to a laminite, with low synoptic relief connecting with adjacent laminae and returning to the columnar morphology again at the very top, in a complex microbialitic deposit. Scale bar: $\mathrm{C}=5 \mathrm{~cm}$. 
alternating with lightly-colored, millimeter-thick laminae of homogeneous microspar, in a light-dark pattern like what has been described by Monty (1976). The vertical transition between one microfabric to the other contributes to lamination. One important microtextural distinction between the lower and the upper stromatolitic cycles is that the former rarely incorporates allochems within laminae, whereas the latter is usually rich in sand-sized coated grains and intraclasts, which most likely originate from the surrounding intraclastic calcarenites that commonly interfered with growth. Stromatolites found in the upper cycle are also characterized by the development of more pervasive fenestrae in relation to its lower counterparts as well as abundant fenestral clotted textures.

In a manner closely resembling the microtextures described in the columnar stromatolites from the upper most cycle of the RSF outcrop, the Bom Despacho examples also commonly incorporate coarser grains, mostly rounded peloids

Table 2. Summary of the distribution of microfabrics amongst the samples analyzed.

\begin{tabular}{|c|c|c|c|c|c|c|}
\hline & \multirow[b]{2}{*}{ Dense micrite } & \multirow[b]{2}{*}{ Fenestral clotted } & \multicolumn{4}{|c|}{ Stromatolitic microfabrics } \\
\hline & & & Peloidal & $\begin{array}{c}\text { Shrub-like / } \\
\text { Filamentous-like }\end{array}$ & $\begin{array}{l}\text { Homogeneous } \\
\text { microspar }\end{array}$ & Sparry calcite \\
\hline $\begin{array}{c}\text { Luz, MG; } \\
\text { RSF outcrop columnar stromatolites }\end{array}$ & $\checkmark$ & $\checkmark$ & & & $\checkmark$ & \\
\hline $\begin{array}{l}\text { Bom Despacho, MG; } \\
\text { Columnar, columnar-layered and strati- } \\
\text { form stromatolites }\end{array}$ & $\checkmark$ & $\checkmark$ & $\checkmark$ & & $\checkmark$ & \\
\hline $\begin{array}{l}\text { São João da Ponte, MG; } \\
\text { Domal stromatolite }\end{array}$ & $\checkmark$ & $\checkmark$ & & $\checkmark$ & & $\checkmark$ \\
\hline $\begin{array}{l}\text { São João da Ponte, MG; } \\
\text { Columnar stromatolite }\end{array}$ & $\checkmark$ & $\checkmark$ & & & & \\
\hline Jaíba, MG; Columnar stromatolites & $\checkmark$ & & & $\checkmark$ & & \\
\hline
\end{tabular}
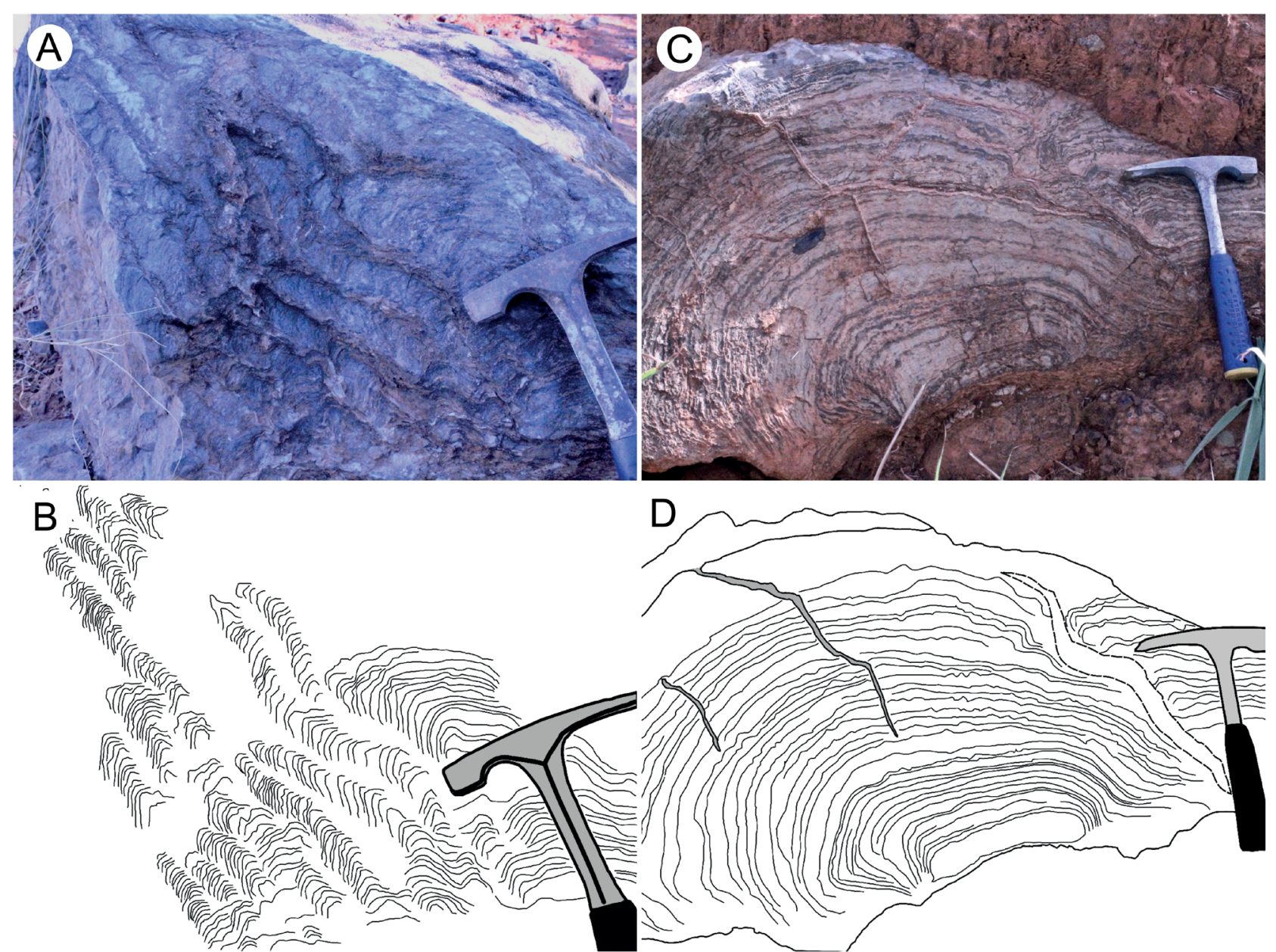

Figure 5. A-B, columnar stromatolites found at the São João da Ponte site. Drawing enables the observation of uniform columns with sinuous growth vectors and alpha, beta and parallel branching patterns. Column with vertically increasing width is also present. $\mathbf{C}-\mathbf{D}$, large, meter-long stromatolitic dome composed of light-dark alternation of rhombic-shaped and moderately convex laminae. Geological hammer is approximately $28 \mathrm{~cm}$ in length. 

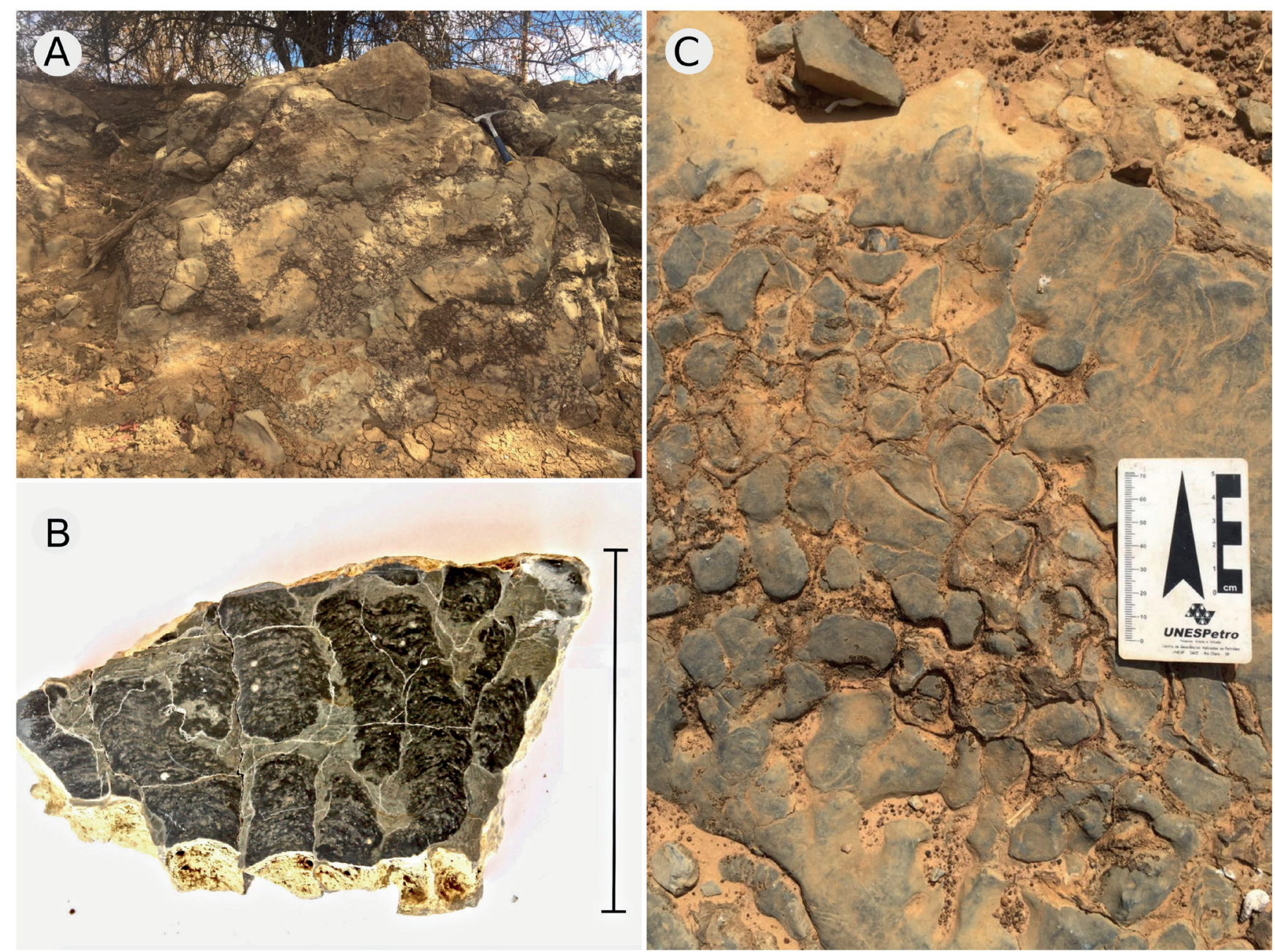

Figure 6. A, overall aspect of the domal bioherms comprised of columnar stromatolites found at the Jaíba site, first reported by Costa (2011). B, polished slab showing columns close to each other with vertical to sinuous growth vectors and tuberous aspect. Note the uneven pattern of the laminae. $\mathbf{C}$, similar stromatolites viewed at plan view, displaying their rounded, elliptical and equidimensional forms. Scale bar: $\mathrm{B}=10 \mathrm{~cm}$.

and coated grains in the fine to medium sand size intervals. In addition, are also distinct in the presence of deep-carving microfractures and fissures, which developed perpendicular to the plane of lamination. Peloidal microfabrics were the most abundant textures described in these stromatolites, followed by the dense micrite and fenestral clotted ones. These peloids may be commonly found on the steep sides of convex laminations, possibly indicating the prevalence of trapping and binding processes. Transition between dense micrite and peloidal horizons are widely responsible for the interface from one lamination to the other.

The northern occurrences, found at São João da Ponte and Jaíba regions, are characterized by the presence of adjacent intraclastic rudstones. They are petrographically defined by a framework composed of poorly-sorted angular intraclasts and other allochems, as well as a lack of carbonate mud. These characteristics closely match what has been previously described as 'flat-pebble conglomerates', common in tidal flat environments with benthic microbial carbonate production (Scholle \& Ulmer-Scholle, 2003). Interestingly, both the columnar, tuberous stromatolites found near Jaíba and the domal occurrence described in the São João da Ponte region developed what is classified here as shrub-like/filamentous-like microfabrics (Figures 7E-F), which are defined as elongated, often branching, treeshaped micrite clumps, with sizes ranging from 500 to 700 $\mu \mathrm{m}$, usually positioned in a vertical mode. Work describing similar textures are reviewed by Riding (2008). In the Jaíba stromatolites these alternate with dense micrite microfabrics in what is an essentially fine-grained (micritic) occurrence, while in the domal form the shrub-like/filamentous-like textures intertwine with sparry calcite horizons (Figure 7E). The branching columns from São João da Ponte mostly developed dense micrite microfabrics with rare fenestrae, being a fine-grained stromatolite. Non-carbonate mineral phases identified include silica, mostly in the form of diagenetic cements, as well as sulfates such as pyrite and phosphatic minerals like apatite. 


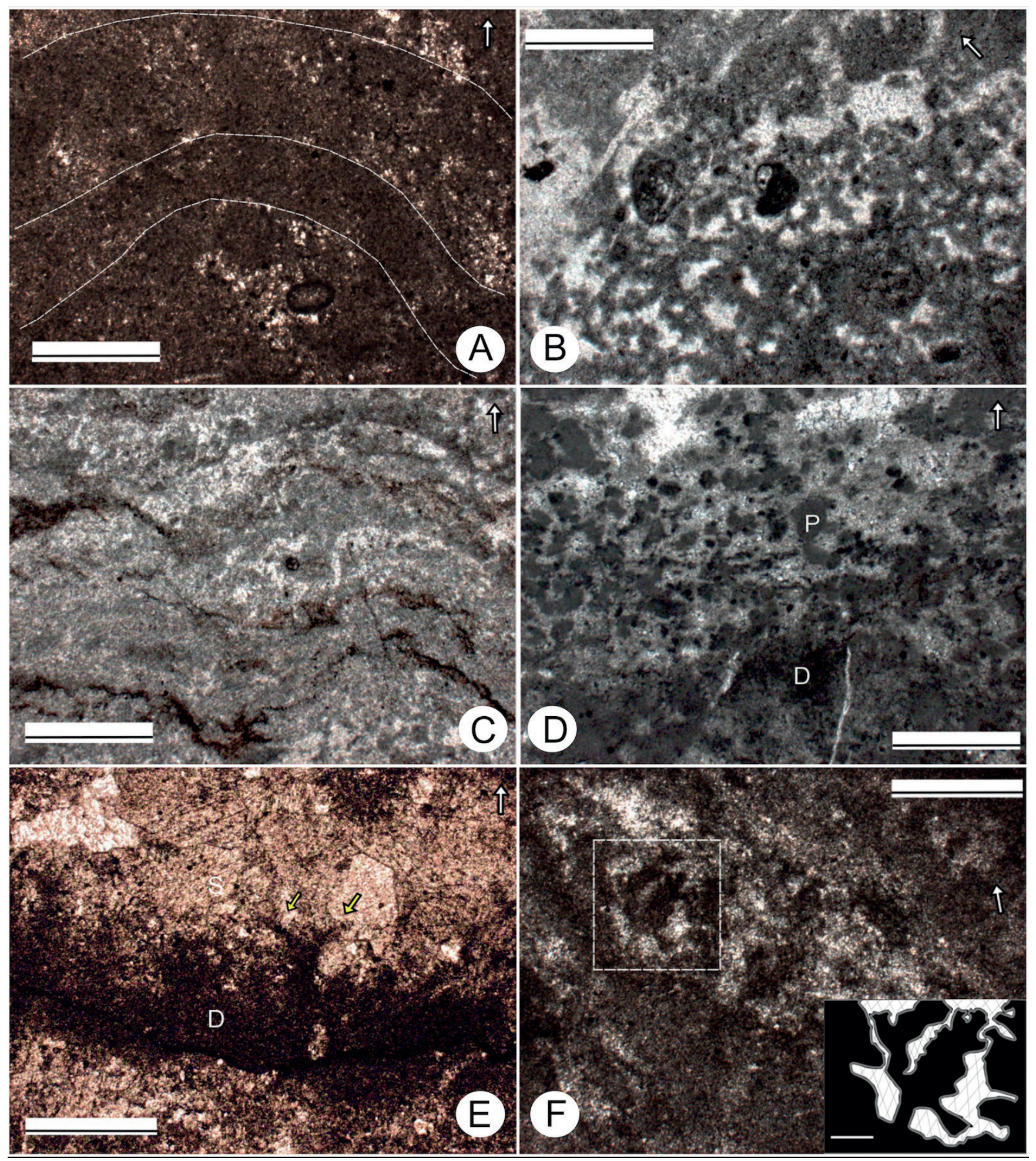

Figure 7. Photomicrographs of the main microfabrics found in the stromatolites of the Lagoa do Jacaré Formation. A, laminae composed of dense micrite microfabrics in sample originating from the columnar stromatolites of the São João da Ponte region. B, classic fenestral clotted or fenestral microclotted microfabrics composed of aggregates and clots of aphanitic micrite forming a complex network of fenestrae. This thin section comes from the upper cycle of the RSF outcrop and exemplifies the common incorporation of allochems, in this case a peloid, within the laminae. C, succession of wavy laminae showing variation of fenestral clotted microfabrics where micrite clumps are more massive and continuous. Note the ill-formed network of fenestra. D, vertical transition between dense micrite microfabrics and poorly-sorted peloidal microfabrics typical of the Bom Despacho stromatolites. E, picture showing the filamentous-like microfabrics observed in the domal stromatolite described here. Filaments were observed to always be oriented towards direction of accretion. F, examples of shrub-like textures in the columnar stromatolites of Jaíba-MG. Tree-shaped structures are all oriented perpendicular to the plane of lamination and commonly branch. This example was observed on the steep side of a moderately convex lamination. Schematic drawing highlights the overall shape and sparry crust surrounding structure. Abbreviations: P, peloidal microfabrics; D, dense micrite microfabrics. Scale bars $=1 \mathrm{~mm}$. All the above images were taken under parallel nicols and $2.5 \mathrm{x}$ magnification. 


\section{DISCUSSION}

Interpreting stromatolites. Inferring the morphological and microtextural aspects of stromatolites in relation to the environments on which they formed has been historically challenging (Walter, 1977; Semikhatov et al., 1979; Bosak et al., 2013) and only a few examples, such as the conical form Conophyton, have some of their morphogenetic processes elucidated by the study of modern analogues and experimental data (Walter, 1972, 1976; Bosak et al., 2009; Petroff et al., 2010).

Barriers to the interpretation of stromatolites arise, partly, from impediments such as the non-uniformitarian aspect of their fossil record. Declining levels of atmospheric $\mathrm{CO}_{2}$ through the Archean and Proterozoic eons influenced the processes governing carbonate precipitation, and, consequently, determined the main stromatolitic microfabrics formed during these periods, which were commonly dominated by inorganically-precipitated sparry calcite crusts during the Archean, transitioning to hybrid crusts composed of interlayering sparry calcite and micrite in the Paleoproterozoic to Mesoproterozoic, and culminating in the development of pervasive fine-grained stromatolitic microfabrics associated with the evolution of $\mathrm{CO}_{2}$-concentrating mechanisms ( $\mathrm{CCM}$ ) in the terminal Proterozoic (Riding, 2006).

Another important factor influencing stromatolite morphology and microstructure would be the biological make up of ecosystems. Awramik et al. (1971) suggested the idea that the rise of metazoans and their so-called 'agronomic revolution' would have deeply affected the development of benthic microbial communities due to increasing pressures from predation and competition for space, although it was received with some skepticism (Riding, 2006). Evolutionary novelties, such as the emergence of large, unicellular, eukaryotic algae, capable of producing larger quantities of EPS (Extracellular Polymeric Substances), may explain the rise of the more recent coarse-grained, agglutinated stromatolites (Awramik \& Riding, 1988).

Despite some confusion, there is some agreement in the literature relating to the influence of broad physical and biological processes in the formation of stromatolites. The work conducted by Logan et al. (1974) with modern examples at Shark Bay, Australia, demonstrated a clear connection between the presence of currents and stromatolite morphology, while Golubic (1976) identified strong correlation between laminae synoptic relief, their microfabric, and the shape of microbial mats.

Bosak et al. (2013) suggested, based on evidence coming from the 750-800-Ma-old biostromes of the Upper Eleonore Bay Group, Greenland, that strong currents and increasing shear stabilized stromatolitic columns and prevented the formation of bridges between structures. Riding (2011) hypothesized that high synoptic relief and intense rates of accretion limit interference by adjacent sediments producing conical and columnar stromatolites, while a low relief structure allows for interference, producing complex, branching structures. A series of physical factors, such as accumulation of detritus on growth surfaces, spacing of stromatolite columns and degree of variability of environmental conditions have also been discussed as influencing factors of stromatolite morphogenesis (Horodyski, 1977).

A general, more balanced view of the importance of physical and biological factors is summarized by Walter (1977), which states that "two forces dominate in stromatolite morphogenesis: water currents and biological reaction to light. In most cases, the balance between these two forces determines the form of the stromatolite". Thus, it follows that in deeper, calmer environments such as the subtidal regions of the carbonate platform on which forms such as Conophyton grew; microbial processes dominated stromatolite morphogenesis, whereas in energetic environments stromatolite morphology is governed by strong tidal currents and differential erosion.

The biogenicity of several stromatolitic microfabrics are discussed in the work reviewed by Riding (2008). Fine-grained microfabrics dominated by dark micrite are generally assumed to be of biological origin, perhaps mainly as a product of sulfate-reducing activity within microbial mats (Pope et al., 2000; Dupraz et al., 2009). On the other hand, calcite fans and sparry crusts may have an inorganic origin (Grotzinger \& James, 2000). Promising data has been recently generated by Suosaari et al. (2016), which identified pervasive micritedominated microfabrics in modern stromatolites of Hamelin Pool, Shark Bay, Australia. These microfabrics were correlated with microbial mats dominated mostly by the cyanobacteria Entophysalis, and are extremely similar to clotted peloidal microfabrics commonly found in Proterozoic stromatolites.

Depositional processes and interpretation. The main processes that were most likely responsible for the formation of the stromatolites here described are discussed below. Finegrained microfabrics such as dense micrite and fenestral clotted textures are generally attributed to biological processes such as the in-situ calcification of microbial mats, and are thus herein interpreted as being essentially biological in nature (Pope et al., 2000; Riding 2008, 2011). The columnar stromatolites found at the lower portion of the RSF outcrop, the tuberous columns from Jaíba and the columnar branching forms of the São João da Ponte are all classified as such. Coarse-grained microtextures like the peloidal microfabrics commonly found in the Bom Despacho columnar stromatolites and laminites are attributed to processes such as the trapping and binding of transported grains and pushed these forms into the coarse agglutinated stromatolite category alongside with the forms with turbinate growth, which incorporate coated grains and intraclasts of the upper RSF outcrop cycle. The domal occurrence of the São João da Ponte region is classified as a hybrid stromatolite, due to its alternating laminae composed of sparry calcite textures and filamentous/shrublike microfabrics essentially comprised of dark micrite. It was most likely a product of cyclic periods of physicochemical precipitation and periods of microbially-induced carbonate precipitation.

In terms of the possible paleoenvironments on which these stromatolites formed, the sedimentological and morphological 
aspects were the most informative. In addition to being fine-grained and not incorporating allochems, the columnar stromatolites of the lower portion of the RSF outcrop are densely packed, and may form bridges, indicating weak currents and shear in what was most likely a low energy, subtidal environment (Bosak et al., 2013). The upper cycle, in the other hand, possesses abundant evidence for being formed closer to the coastal zones, in the form of ooids, oncoids, and intraclasts that are found within stromatolitic laminae as well as in the intercolumnar material. The pervasiveness of fenestral textures and microfractures may also point to a shallow environment where these microbial structures were periodically exposed to subaerial conditions (Riding, 1991). They are here interpreted to have been deposited in a high intertidal to supratidal environments. Similar conditions are also thought to have been present during the formation of the Bom Despacho stromatolites, as they possess most of the features one would expect from such an environment, like the common trapping of transported grains and development of fenestrae and fractures due to subaerial exposure, as mentioned above.

The bioherms found at the northern localities are all characterized by abundant deposition of intraclast grainstones and rudstones adjacent to the bioherms, which are interpreted to represent energetic events, such as occasional storms, eroding the stromatolites and depositing coarse, elongated reworked fragments, mostly likely on an intertidal environment. This echoes Sami \& James (1993) in their observation that intraclasts are common in Proterozoic shelf and ramps, and are much more likely to have been generated by storm wave erosion than fair-weather events, as benthic environments were extensively covered by microbial mats cementing the sea floor. Those events likely precluded the formation of columns during the time interval in which the domal morphology developed at the São João da Ponte site (Horodyski, 1977), but were not long lasting as the columnar branching forms occur in a slightly stratigraphically upper level.

Inferences about the biological compostion of these ancient microbial communities could also be drawn from the data presented above. Despite being readily available, coarse-grained sediments were not incorporated within the stromatolitic laminae of occurrences such as the columnar and domal forms of Jaíba and São João da Ponte, which may indicate that the benthic microbial communities were essentially prokaryotic, as eukaryotic cells tend to be larger and may potentially trap coarser grains (Awramik \& Riding, 1988).

Shrub-like microfabrics biogenicity. Discussion regarding the biological origins of microfossil-like microtextures in Precambrian rocks has been focused mainly on the putative Archean microfossils preserved in chert deposits, and proved highly contentious, even requiring the development of a set of identifiable characters to verify biogenicity (Buick, 1990; Hofmann, 2004; Brasier et al., 2005). On the other hand, few doubt the biological influence of benthic microbial communities in the genesis of Neoproterozoic and early Paleozoic stromatolites, with several authors reporting the presence of filamentous, shrub-like and bushy calcimicrobial microtextures like the ones herein reported (Riding \& Voronova, 1982; Turner et al., 2000; Kah \& Riding, 2007). They are usually observed to have irregular margins, being hundreds of microns in length, are usually vertically oriented in relation to the plane of accretion and may occur in tandem with sparry calcite laminations (see Riding, 2008 for a review).

\section{CONCLUSIONS}

Given the new information presented here regarding previously undescribed stromatolite occurrences in the Lagoa do Jacaré Formation, the following conclusions could be drawn: (i) despite not possessing within its sedimentological definitions the occurrence of stromatolites and other microbialites, the Lagoa do Jacaré Formation contains a relatively diverse assemblage of stromatolitic forms not previously recognized prior to this publication; (ii) morphologies include low synoptic relief forms such as laminites and columnar-layered microbialitic complexes, varied columnar forms, including sinuous, tuberous and branching patterns, as well as large, meter-long domal occurrences; (iii) southern occurrences commonly incorporated coarser grains within stromatolitic laminations, such as coated grains and peloids within its microbial laminations, indicating a stronger trapping and binding component in its genesis. Also, they commonly presented possible exposure textures such as extensive fenestrae and cement-filled fractures; (iv) stromatolite systems described in the northern regions of the State of Minas Gerais, on the other hand, preserved shrub-like microfabrics and did not incorporate allochems within its laminations, despite abundant supply of storm-deposited intraclastic rudstones; (v) the northern occurrences were inferred here to have been deposited in a intertidal environment, while stromatolites found in the south commonly present evidence for formation in close proximity to the shore face, likely on a high intertidal to supratidal gradient, such as the presence of wave-breaking zone grains like ooids and oncoids.

\section{ACKNOWLEDGEMENTS}

We would like to thank T.R. Fairchild (USP) and L.V. Cruz (UnB) for their kind comments. We also thank the staff at the geochronology (Geochronos) and paleontology (Palaios) laboratories at the University of Brasília for their support. The present work is part of the project entitled "The Microbialites of the State of Minas Gerais", an interinstitutional endeavor which originated at PRPPG/ UFVJM (11082016). This study was financed in part by the Coordenação de Aperfeiçoamento de Pessoal de Nível Superior - Brasil (CAPES) - Finance Code 001. 


\section{REFERENCES}

Alvarenga, C.J.; Figueiredo, M.F.; Babinski, M. \& Pinho, F.E. 2007. Glacial diamictites of Serra Azul Formation (Ediacaran, Paraguay belt): evidence of the Gaskiers glacial event in Brazil. Journal of South American Earth Sciences, 23:236-241. doi:10.1016/j.jsames.2006.09.015

Awramik, S.M. 1971. Precambrian columnar stromatolite diversity: reflection of metazoan appearance. Science, 174:825-827. doi:10.1126/science.174.4011.825

Awramik, S.M. \& Riding, R. 1988. Role of algal eukaryotes in subtidal columnar stromatolite formation. Proceedings of the National Academy of Sciences, 85:1327-1329. doi:10.1073/ pnas.85.5.1327

Babinski, M.; Vieira, L.C. \& Trindade, R.I.P. 2007. Direct dating of the Sete Lagoas cap carbonate (Bambuí Group, Brazil) and implications for the Neoproterozoic glacial events. Terra Nova, 19:401-406. doi:10.1111/j.1365-3121.2007.00764.x

Bosak, T.; Knoll, A.H. \& Petroff, A.P. 2013. The meaning of stromatolites. Annual Review of Earth and Planetary Sciences, 41:21-44. doi:10.1146/annurev-earth-042711-105327

Bosak, T.; Liang, B.; Sim, M.S. \& Petroff, A.P. 2009. Morphological record of oxygenic photosynthesis in conical stromatolites. Proceedings of the National Academy of Sciences, 106:1093910943. doi:10.1073/pnas.0900885106

Brasier, M.D.; Green, O.R.; Lindsay, J.F.; McLoughlin, N.; Steele, A. \& Stoakes, C. 2005. Critical testing of Earth's oldest putative fossil assemblage from the $\sim 3.5$ Ga Apex chert, Chinaman Creek, Western Australia. Precambrian Research, 140:55-102. doi:10.1016/j.precamres.2005.06.008

Buick, R. 1990. Microfossil recognition in Archean rocks: an appraisal of spheroids and filaments from a 3500 my old chertbarite unit at North Pole, Western Australia. Palaios, 5:441-459. doi:10.2307/3514837

Costa, D.A. 2011. Controle lito-estrutural e estratigráfico na hidrogeoquímica e nas concentrações de fluoreto no sistema aquífero cárstico-fissural do Grupo Bambui, norte de Minas Gerais. Programa de Pós-Graduação em Geologia, Universidade Federal de Minas Gerais, Dissertação de Mestrado, 138 p.

Costa, M.D. \& Branco, J.J.R. 1961. Roteiro para a excursão Belo Horizonte-Brasília. In: CONGRESSO BRASILEIRO DE GEOLOGIA, 15, 1961. Resumos, Belo Horizonte, SBG, p. 9-25.

Cunha, R.B. 2012. Quimioestratigrafia 87SR/86SR das rochas carbonáticas do grupo Bambuí. Monografia de conclusão do curso em Geologia, Universidade Federal do Rio Grande do Sul, 79 p.

Dardenne, M.A. 1978a. Zonação tectônica na borda ocidental do Cráton do São Francisco. In: CONGRESSO BRASILEIRO DE GEOCIÊNCIAS, 30, 1978. Anais, SBG, p. 299-308.

Dardenne, M.A. 1978b. Síntese sobre a estratigrafia do Grupo Bambuí no Brasil Central. In: CONGRESSO BRASILEIRO DE GEOCIÊNCIAS, 30, 1978. Anais, SBG, p. 597-610.

Dardenne, M.A. \& Walde, D.H.G. 1979. A estratigrafia dos Grupos Bambuí e Macaúbas no Brasil central. In: SIMPÓSIO DE GEOLOGIA DE MINAS, 1, 1979. Resumos, SBG, p. 43-54.

Dardenne, M.A. 2000. The Brasília fold belt. In: INTERNATIONAL GEOLOGICAL CONGRESS, 31, 2000. Proceedings, Rio de Janeiro, IUGS, p. 231-263.

Derby, O.A. 1878. Contribuição para o estudo da geologia do vale do São Francisco. Arquivos do Museu Nacional, 4:87-119.

Dupraz, C.; Reid, R.P.; Braissant, O.; Decho, A.W.; Norman, R.S. \& Visscher, P.T. 2009. Processes of carbonate precipitation in modern microbial mats. Earth-Science Reviews, 96:141-162. doi:10.1016/j.earscirev.2008.10.005

Fairchild, T.R. \& Sanchez, E.A.M. 2015. Microbialitos no Brasil: panorâmica de ocorrências e guia de caracterização morfológica. In: T.R. Fairchild; R. Rohn \& D. Dias-Brito (eds.) Microbialitos do Brasil do Pré-Cambriano ao Recente: um atlas, UNESPetro, p. 10-20.

Fragoso, D.G.C.; Uhlein, A.; Sanglard, J.C.D.; Suckau, G.L.; Guerzoni, H.T.G. \& Faria, P.H. 2013. Geologia dos grupos Bambuí, Areado e Mata da Corda na folha Presidente Olegário (1:100.000), MG: registro deposicional do Neoproterozóico ao Neocretáceo da Bacia do São Francisco. Revista Geonomos, 19:28-38. doi:10.18285/geonomos. v19i1.60

Golubic, S. 1976. Organisms that build stromatolites. In: M.R. Walter (ed.) Stromatolites, Amsterdam, Elsevier, p. 113-126 (Developments in Sedimentology 20). doi:10.1016/S00704571(08)71132-4

Grotzinger, J.P. \& James, N.P. 2000. Precambrian carbonates: evolution of understanding. In: J. Grotzinger \& N. James (eds.) Carbonate sedimentation and diagenesis in the evolving Precambrian world, Tulsa, The Society for Sedimentary Geology, p. 3-22 (Special Publication 67).

Grotzinger, J.P.; Watters, W.A. \& Knoll, A.H. 2000. Calcified metazoans in thrombolite-stromatolite reefs of the terminal Proterozoic Nama Group, Namibia. Paleobiology, 26:334-359. doi:10.1666/0094-8373(2000)026<0334:CMITSR > 2.0.CO;2

Hahn, G.; Hahn, R.; Leonardos, O.H.; Pflug, H.D. \& Walde, D.H.G. 1982. Körperlich erhaltene Scyphozoen-Reste aus dem Jungpräkambrium Brasiliens. Geologica et Palaeontologica, 16:1-18.

Hofmann, H.J. 2004. Archean microfossils and abiomorphs. Astrobiology, 4:135-136. doi:10.1089/153110704323175115

Horodyski, R.J. 1977. Environmental influences on columnar stromatolite branching patterns: examples from the Middle Proterozoic Belt Supergroup, Glacier National Park, Montana. Journal of Paleontology, 51:661-671.

Iglesias, M. \& Uhlein, A. 2009. Estratigrafia do Grupo Bambuí e coberturas fanerozóicas no vale do rio São Francisco, norte de Minas Gerais. Revista Brasileira de Geociências, 39:256-266.

Kah, L.C. \& Riding, R. 2007. Mesoproterozoic carbon dioxide levels inferred from calcified cyanobacteria. Geology, 35:799-802. doi:10.1130/G23680A.1

Kuchenbecker, M. 2014. Relações entre coberturas do Cráton do São Francisco e bacias situadas em orógenos marginais: $o$ registro de datações $\mathrm{U}-\mathrm{Pb}$ de grãos detríticos de zircão $e$ suas implicações geotectônicas. Programa de Pós-Graduação em Geologia, Universidade Federal de Minas Gerais, Tese de doutorado, $163 \mathrm{p}$.

Kuchenbecker, M.; Atman, D.; Costa, R.D.; Pedrosa-Soares, A.C. \& Babinski, M. 2016. A Formação Gorutuba: sedimentação litorânea a continental na margem leste da Bacia Bambuí (MG). Geologia USP, 16:67-81. doi:10.11606/issn.2316-9095.v16i2p67-81

Kuchenbecker, M. \& Pedrosa-Soares, A.C. 2013. O Grupo Bambuí na folha Luz (SE-23-YDV). Revista Geonomos, 18:46-52. doi:10.18285/geonomos.v18i2.71

Logan, B.W.; Hoffman, P. \& Gebelein, C.D. 1974. Algal mats, cryptalgal fabrics, and structures, Hamelin Pool, Western Australia. In: B.W. Logan; J.F. Read; G.M. Hagan; P. Hoffman; R.G. Brown; P.J. Woods \& C.D. Gebelein (eds.) Evolution and diagenesis of quaternary carbonate sequences, Shark Bay, western Australia, American Association of Petroleum Geologists, p. 140-194.

Logan, B.W.; Rezak, R. \& Ginsburg, R.N. 1964. Classification and environmental significance of algal stromatolites. The Journal of Geology, 72:68-83. doi:10.1086/626965

Marchese, H.G. 1974. Estromatólitos Gymnosolenides en el lado oriental de Minas Gerais, Brasil. Revista Brasileira de Geociências, 4:257-272.

Martins-Neto, M.A. 2007. Proterozoic first-order sedimentary successions of the São Francisco Basin in eastern Brazil. Zeitschrift der Deutschen Gesellschaft für Geowissenschaften, 158:31-43. doi:10.1127/1860-1804/2007/0158-0031 
Maury, C.J. 1929. Calcário fossilifero de Bom Jesus da Lapa, Bahia. Rio de Janeiro, Serviço Geológico e Mineral do Brasil, p. 46-53 (Monografias 7).

Monty, C.L.V. 1976. The origin and development of cryptalgal fabrics. In: M.R. Walter (ed.) Stromatolites, Amsterdam, Elsevier, p. 193-249 (Developments in Sedimentology 20). doi:10.1016/S0070-4571(08)71137-3

Paula-Santos, G.M.; Babinski, M.; Caetano-Filho, S. \& Kuchenbecker, M. 2012. Abordagem quimioestratigráfica (C,O) e geocronológica da Formação Sete Lagoas na região de Vespasiano, MG: uma unidade cambriana. In: CONGRESSO BRASILEIRO DE GEOLOGIA, 46, 2012. Anais, Santos, SBG, CD.

Paula-Santos, G.M.; Babinski, M.; Kuchenbecker, M.; CaetanoFilho, S.; Trindade, R.I. \& Pedrosa-Soares, A.C. 2015. New evidence of an Ediacaran age for the Bambuí Group in southern São Francisco craton (eastern Brazil) from zircon U-Pb data and isotope chemostratigraphy. Gondwana Research, 28:702-720. doi:10.1016/j.gr.2014.07.012

Paula-Santos, G.M.; Caetano-Filho, S.; Babinski, M. \& Enzweiler, J. 2018. Rare earth elements of carbonate rocks from the Bambuí Group, southern São Francisco Basin, Brazil, and their significance as paleoenvironmental proxies. Precambrian Research, 305:327-340. doi:10.1016/j.precamres.2017.12.023

Petroff, A.P.; Sim, M.S.; Maslov, A.; Krupenin, M.; Rothman, D.H. \& Bosak, T. 2010. Biophysical basis for the geometry of conical stromatolites. Proceedings of the National Academy of Sciences, 107:9956-9961. doi:10.1073/pnas.1001973107

Pimentel, M.M.; Della Giustina, M.E.S.; Rodrigues, J.B. \& Junges, S.L. 2012. Idades dos grupos Araxá e Bambuí: implicações para a evolução da Faixa Brasília. In: CONGRESSO BRASILEIRO DE GEOLOGIA, 46, 2012. Anais, Santos, SBG, CD.

Pimentel, M.M.; Rodrigues, J.B.; DellaGiustina, M.E.S.; Junges, S.; Matteini, M. \& Armstrong, R. 2011. The tectonic evolution of the Neoproterozoic Brasília Belt, central Brazil, based on SHRIMP and LA-ICPMS U-Pb sedimentary provenance data: a review. Journal of South American Earth Sciences, 31:345-357. doi:10.1016/j.jsames.2011.02.011

Pope, M.C.; Grotzinger, J.P. \& Schreiber, B.C. 2000. Evaporitic subtidal stromatolites produced by in situ precipitation: textures, facies associations, and temporal significance. Journal of Sedimentary Research, 70:1139-1151. doi:10.1306/062099701139

Preiss, W.V. 1976. Basic field and laboratory methods for the study of stromatolites. In: M.R. Walter (ed.) Stromatolites, Amsterdam, Elsevier, p. 5-13 (Developments in Sedimentology 20). doi:10.1016/S0070-4571(08)71124-5

Ribeiro, J.H.; Tuller, M.P.; Signorelli, N. \& Féboli, W.L. 2008. Mapa Geológico da Folha Bom Despacho (1:100.000). Belo Horizonte, CPRM.

Riding, R. 1977. Skeletal stromatolites. In: E. Flügel (ed.) Fossil algae, Springer, p. 57-60. doi:10.1007/978-3-642-66516-5_4

Riding, R. 1991. Classification of microbial carbonates. In: R. Riding (ed.) Calcareous algae and stromatolites, Springer, p. $51-51$. doi:10.1007/978-3-642-52335-9 2

Riding, R. 2006. Cyanobacterial calcification, carbon dioxide concentrating mechanisms, and Proterozoic-Cambrian changes in atmospheric composition. Geobiology, 4:299-316. doi:10.11 $11 / j .1472-4669.2006 .00087$

Riding, R. 2008. Abiogenic, microbial and hybrid authigenic carbonate crusts: components of Precambrian stromatolites. Geologia Croatica, 61:73-103.

Riding, R. 2011. Microbialites, stromatolites, and thrombolites. In: J. Reitner \& V. Thiel (eds.) Encyclopedia of Geobiology, Springer, p. 635-654. doi:10.1007/978-1-4020-9212-1_196

Riding, R. \& Voronova, L. 1982. Recent freshwater oscillatoriacean analogue of the Lower Palaeozoic calcareous alga Angulocellularia. Lethaia, 15:105-114. doi:10.1111/j.1502-3931.1982.tb01983.x
Rodrigues, J.B. 2008. Proveniência de sedimentos dos grupos Canastra, Ibiá, Vazante e Bambui: um estudo de zircões detríticos e idades modelo Sm-Nd. Programa de Pós-Graduação em Geologia, Universidade de Brasília, Tese de Doutorado, 128 p.

Sami, T.T. \& James, N.P. 1993. Evolution of an early Proterozoic foreland basin carbonate platform, lower Pethei Group, Great Slave Lake, north-west Canada. Sedimentology, 40:403-430. doi:10.1111/j.1365-3091. 1993.tb01343.x

Sanchez, E.A.M. 2014. Microbialitos e microfósseis da Formação Sete Lagoas, Neoproterozoico, Brasil: implicações geomicrobiológicas em um contexto de mudanças climáticas e evolutivas. Programa de Pós-Graduação em Geologia, Universidade de São Paulo, Tese de Doutoramento, 298 p.

Scholle, P.A. \& Ulmer-Scholle, D.S. 2003. A Colour guide to the petrography of carbonate rocks: grains, textures, porosity, diagenesis. Tulsa, American Association of Petroleum Geologists, 461 p. (Memoir 77). doi:10.1306/M77973

Semikhatov, M.A.; Gebelein, C.D.; Cloud, P.; Awramik, S.M. \& Benmore, W.C. 1979. Stromatolite morphogenesis-progress and problems. Canadian Journal of Earth Sciences, 16:992-1015. doi:10.1139/e79-088

Sial, A.N. et al. 2009. The São Francisco paleocontinent. In: C. Gaucher; A.N. Sial; G.P. Halverson \& H.E. Frimmel (eds.) Neoproterozoic-cambrian tectonics, global change and evolution, Amsterdam, Elsevier, p. 31-69 (Developments in Precambrian 16). doi:10.1016/S0166-2635(09)01603-X

Suosaari, E.P.; Reid, R.P.; Playford, P.E.; Foster, J.S.; Stolz, J.F.; Casaburi, G.; Hagan, P.D.; Chirayath, V.; Macintyre, I.G.; Planavsky, N.J. \& Eberli, G.P. 2016. New multi-scale perspectives on the stromatolites of Shark Bay, Western Australia. Scientific Reports, 6:20557. doi:10.1038/srep20557

Turner, E.C.; James, N.P. \& Narbonne, G.M. 2000. Taphonomic control on microstructure in Early Neoproterozoic reefal stromatolites and thrombolites. Palaios, 15:87-111. doi:10.1669/0883-1351(2000)015<0087:TCOMIE >2.0.CO;2

Uhlein, G.J.; Uhlein, A.; Stevenson, R.; Halverson, G.P.; Caxito, F.A. \& Cox, G.M. 2017. Early to Late Ediacaran conglomeratic wedges from a complete foreland basin cycle in the southwest São Francisco Craton, Bambuí Group, Brazil. Precambrian Research, 299:101-116. doi:10.1016/j.precamres.2017.07.020

Walter, M.R. 1972. Stromatolites and the biostratigraphy of the Australian Precambrian and Cambrian. London, The Palaeontological Association, 256 p. (Special Papers in Palaeontology 11).

Walter, M.R. 1976. Microbiology and morphogenesis of columnar stromatolites (Conophyton, Vacerilla) from hot springs in Yellowstone National Park. In: M.R. Walter (ed.) Stromatolites, Amsterdam, Elsevier, p. 273-310 (Developments in Sedimentology 20). doi:10.1016/S0070-4571(08)71140-3

Walter, M.R. 1977. Interpreting Stromatolites: these fossils can tell us much about past organisms and environments if we can learn to decode their message. American Scientist, 65:563-571.

Warren, L.V.; Quaglio, F.; Riccomini, C.; Simões, M.G.; Poiré, D.G.; Strikis, N.M.; Anelli, L.E. \& Strikis, P.C. 2014. The puzzle assembled: Ediacaran guide fossil Cloudina reveals an old proto-Gondwana seaway. Geology, 42:391-394. doi:10.1130/ G35304.1

Received in 21 March, 2018; Accepted in 13 November, 2018. 